\title{
Salvage Logging, Ecosystem Processes, and Biodiversity Conservation
}

\author{
D.B. LINDENMAYER* AND R.F. NOSS $†$
}

${ }^{*}$ Centre for Resource and Environmental Studies, The Australian National University, Canberra, ACT 0200, Australia, email davidl@cres.anu.edu.au

†Department of Biology, University of Central Florida, Orlando, Florida 32816-2368, U.S.A.

\begin{abstract}
We summarize the documented and potential impacts of salvage logging-a form of logging that removes trees and other biological material from sites after natural disturbance. Such operations may reduce or eliminate biological legacies, modify rare postdisturbance habitats, influence populations, alter community composition, impair natural vegetation recovery, facilitate the colonization of invasive species, alter soil properties and nutrient levels, increase erosion, modify bydrological regimes and aquatic ecosystems, and alter patterns of landscape beterogeneity. These impacts can be assigned to three broad and interrelated effects: (1) altered stand structural complexity; (2) altered ecosystem processes and functions; and (3) altered populations of species and community composition. Some impacts may be different from or additional to the effects of traditional logging that is not preceded by a large natural disturbance because the conditions before, during, and after salvage logging may differ from those that characterize traditional timber harvesting. The potential impacts of salvage logging often have been overlooked, partly because the processes of ecosystem recovery after natural disturbance are still poorly understood and partly because potential cumulative effects of natural and buman disturbance bave not been well documented. Ecologically informed policies regarding salvage logging are needed prior to major natural disturbances so that when they occur ad boc and crisis-mode decision making can be avoided. These policies should lead to salvage-exemption zones and limits on the amounts of disturbance-derived biological legacies (e.g., burned trees, logs) that are removed where salvage logging takes place. Finally, we believe new terminology is needed. The word salvage implies that something is being saved or recovered, whereas from an ecological perspective this is rarely the case.
\end{abstract}

Keywords: forest management, human disturbance, natural disturbance

Cosecha de Salvamento, Procesos Ecológicos y Conservación de la Biodiversidad

Resumen: Resumimos los impactos documentados y potenciales de la cosecha de salvamento - una forma de cosecha de madera que remueve árboles y otros materiales biológicos después de una perturbación natural. Tales operaciones pueden reducir o eliminar legados biológicos, modificar hábitats post perturbación, influir en poblaciones, alterar la composición de comunidades, impedir la recuperación de la vegetación natural, facilitar la colonización de especies invasoras, alterar las propiedades del suelo y de niveles de nutrientes, incrementar la erosión, modificar regímenes bidrologicos y ecosistemas acuáticos, y alterar patrones de beterogeneidad del paisaje. Estos impactos se pueden asignar a tres efectos amplios e interrelacionados: (1) alteración de la complejidad estructural del bosque; (2) alteración de procesos y funciones ecológicas; y (3) alteración de poblaciones de especies y de la composición de la comunidad. Algunos impactos pueden ser diferentes a o adicionales a los efectos de la cosecha de madera tradicional que no es precedida de una perturbación natural severa porque las condiciones antes, durante y después de la cosecha de salvamento pueden diferir de las que caracterizan a la cosecha de madera tradicional. Los impactos potenciales de la cosecha de salvamento a menudo han sido pasados por alto, en parte porque los procesos de recuperación del ecosistema después de una perturbación natural son poco conocidos y en parte porque los efectos acumulativos potenciales de

Paper submitted November 9, 2005; revised manuscript accepted April 18, 2006. 
perturbaciones naturales y bumanas no han sido bien documentados. Se requieren políticas ecológicamente informadas para la cosecha de salvamento para que cuando ocurran las perturbaciones naturales se evite la toma de decisiones en situaciones de crisis. Estas políticas deberán establecer zonas exentas de salvamento y límites a las cantidades de legados biológicos derivados de la perturbación (e. g., árboles quemados, troncos) que son removidos donde se lleva a cabo la cosecha de salvamento. Finalmente, creemos que se requiere una nueva terminología. La palabra salvamento implica que algo esta siendo salvado o recuperado, y este raramente es el caso desde una perspectiva ecológica.

Palabras Clave: conservación de la biodiversidad, gestión forestal, procesos ecosistémicos

\section{Introduction}

Large-scale natural disturbances, including wildfires, floods, mudslides, volcanic eruptions, earthquakes, tsunamis, insect attacks, windstorms, and hurricanes occur at varying intervals in most ecosystems worldwide (Holling et al. 1995; Bryant 2001; Schoener et al. 2004). In many cases major efforts are mounted to "clean up" after natural disturbances (Robinson \& Zappieri 1999; Beschta et al. 2004). This is particularly true in forest landscapes where salvage harvesting of disturbed stands is widely practiced for such reasons as recouping economic losses before serious deterioration of trees occurs (Ulbricht et al. 1999; Shore et al. 2003) and ostensibly assisting ecosystem recovery (e.g., by speeding the reestablishment of forest cover) (Sessions et al. 2004). Questionable assumptions used to justify salvage include the perception that naturally disturbed areas have limited value for biota (Morissette et al. 2002), that damaged trees will attract insects that will attack adjacent undisturbed stands (Amman \& Ryan 1991), and that dead trees create abundant fuels and an increased fire risk and threat to public safety (Ne'eman et al. 1997; Shore et al. 2003).

The published literature is replete with studies of the impacts of traditional (nonsalvage) forms of logging on individual elements of the biota, the structure and composition of stands, landscape patterns and composition, and key ecosystem processes and functions (Hunter 1999; Lindenmayer \& Franklin 2002; Burton et al. 2003). Considerably less work has been conducted on salvage logging (McIver \& Starr 2001; Beschta et al. 2004; Karr et al. 2004), and much of that is in gray literature, which can be difficult to obtain. A key issue is whether the impacts of salvage logging are different from, and potentially more detrimental than, other forms of logging that are not preceded by a major natural disturbance. Conditions that precede logging, conditions under which logging occurs, type and characteristics of trees logged, and logging practices applied may all differ between salvage logging and conventional logging, and these differences may have important influences on the maintenance of ecosystem processes and biodiversity.

Special environmental conditions may precede major natural disturbance events. For example, extensive soil wetting occurs before the high winds associated with hurricanes and cyclones (Elliott et al. 2002). Prolonged droughts and high temperatures are typical before wildfires in some forest types (Bradstock et al. 2002), and these can exert strong influences on many organisms (Rübsamen et al. 1984).

Salvage logging is conducted in disturbed ecosystems. In such ecosystems the organic component of soils may have been burned or mineral soil exposed, which can make soils vulnerable to additional impacts such as those associated with salvage logging (Shakesby et al. 1996; McIver \& Starr 2000, 2001).

Salvage logging involves the removal of particular trees or stands that are often uncommon, such as charred standing stems, recently windblown trees, trees partially immersed in volcanic ash, or the largest trees that remainbecause of their economic value (Morissette et al. 2002). Conditions following stand-replacing disturbances in many regions are among the most biologically diverse and most imperiled of all forest conditions (Franklin \& Agee 2003).

Salvage logging sometimes takes place in ways that are more intensive or extensive than traditional forms of $\log$ ging (McIver \& Starr 2000; van Nieuwstadt et al. 2001) or in areas where traditional logging might not normally occur. For example, harvesting operations may affect soils that have been previously altered by fire, cutover sizes can be larger (Radeloff et al. 2000), and road networks more extensive.

Given these differences between traditional harvesting and salvage logging and that salvage logging is a combination of disturbances, a fundamental question is, does salvage logging have different and/or additional effects than either a natural disturbance alone or traditional logging alone? Answering this question is difficult because salvage logging has received relatively little attention from ecologists and conservation biologists (Morissette et al. 2002) and significant limitations plague many of the studies that have been completed (McIver \& Starr 2000). Hence, salvage policies sympathetic to conservation concerns are not well developed in many jurisdictions (e.g., Quebec in Nappi et al. 2003; Lindenmayer et al. 2004).

The contributions to this special section of Conservation Biology attempt to redress some of the problems 
created by the lack of knowledge and understanding of the impacts of salvage logging. As a prelude to the case studies, we provide a brief overview of the potential impacts of salvage logging on biota and ecosystem processes. Our review is based on a systematic search of the literature for published material on salvaging. We accessed biological databases and scanned citation lists of papers dedicated to the topic. We build on an earlier review by McIver and Starr (2000), which examines literature on postfire salvage logging up to mid-1998, primarily in western N. America, and add information from other parts of the world as well as make some important salvageharvesting policy recommendations. Given limited space, our overview is indicative of the sorts of impacts that may accompany salvage logging rather than a comprehensive and exhaustive treatment of the literature. Most of our discussion relates to those forest ecosystems where salvaging is most prevalent.

\section{Definitions and Background}

We broadly define salvage logging as the harvesting of trees and other biological material from areas after natural, or sometimes human-caused, disturbance events. Salvage logging is practiced after floods (Gregory 1997), volcanic eruptions (Franklin \& MacMahon 2000), wildfires (Stuart et al. 1993; McIver \& Starr 2000; Nappi et al. 2004), insect attacks (Radeloff et al. 2000; Brooks 2001; Shore et al. 2003), and hurricanes, cyclones, and windstorms (Foster et al. 1997; Elliott et al. 2002; Greenberg 2002). Salvage harvesting is widespread and occurs in temperate (Morissette et al. 2002) and tropical forests (van Niewenstadt et al. 2001). It is most prevalent in ecosystems where natural disturbances, particularly wildfires and insect attacks, are stand-replacing or partial stand-replacing events (Nappi et al. 2004; reviewed by McIver \& Starr 2000).

Salvage logging has been practiced for a long time. For example, extensive salvaging occurred after a major hurricane in northeastern United States in 1938 (Foster et al. 1997). Similarly, wet eucalypt forests in eastern Australia were salvage harvested following wildfires in 1926, 1932, and 1939 (Lindenmayer \& Ough 2006 [this issue]). Forests in western Oregon (U.S.A.) damaged in the 1933 Tillamook burn were salvaged until at least 1959 (J. Franklin, personal communication).

\section{Natural Disturbance Regimes and Ecosystem Dynamics}

Prior to examining some of the potential impacts of salvaging logging, we provide context to our discussion by outlining some modern perspectives on the role of natural disturbance in ecosystem dynamics. Part of the motivation for salvage logging is underpinned by common perceptions of events such as wildfires, hurricanes, or floods as disasters or catastrophes. The affected landscapes are widely referred to as "destroyed," "damaged," "consumed," or "lost" - terms sometimes even used by ecologists (e.g., Ne'eman et al. 1997).

In contrast to past characterizations of disturbances as disasters that need cleaning up, it has become clear that natural disturbances are key processes in the majority of ecosystems (Pahl-Wostl 1995). Indeed, recent paradigms in ecology emphasize both the dynamic, nonequilibrial nature of ecological systems of which disturbance is a recurring feature (Pickett et al. 1992; Holling et al. 1995) and the interrelationships between natural disturbance regimes and the maintenance of biodiversity (Hansen \& Rotella 1999; Bradstock et al. 2002; Shiel \& Burslem 2003). An increasing body of evidence indicates that many species and ecosystems have evolved with, and are adapted to, various types of natural disturbance (Rülker et al. 1994; Bunnell 1995; Bradstock et al. 2002). Good empirical data also exist on natural recovery processes in intensively disturbed ecosystems, for instance the response of the Greater Yellowstone Ecosystem following the 1988 conflagration there (Turner et al. 2003) and the Mt. St. Helens ecosystem following the 1980 volcanic eruption (Franklin \& MacMahon 2000).

\section{Potential Impacts of Salvage Harvesting}

As in the case of conventional logging, the impacts of salvage logging vary in response to a wide range of factors, including the ecosystem, ecological processes, and particular elements of the biota in question; the type, intensity, frequency, and spatial pattern of logging and the preceding natural disturbance; and the potential cumulative impacts of the type and intensity of a preceding natural disturbance coupled with logging pattern, intensity, and frequency. Generalizing from the limited research to date, the impacts of salvage logging can be classified into three broad categories: (1) impacts on the physical structure of forest stands and aquatic systems; (2) impacts on key ecosystem processes (e.g., hydrological cycles, nutrient cycling, and soil formation); and (3) impacts on particular elements of the biota and species assemblages. These impacts, considered below, are often interrelated and cumulative.

\section{Salvage Harvesting, Stand Structural Complexity, and Biodiversity Responses}

Patterns of ecosystem recovery and revitalization, together with the recovery of many elements of the biota within these ecosystems, are influenced by the types, numbers, and spatial arrangements of biological legacies remaining following natural disturbance (Lindenmayer \& Franklin 2002). Biological legacies are organisms, organically derived structures, and organically produced 
Table 1. Ecological roles of biological legacies* on patterns of ecosystem recovery and revitalization.

\begin{tabular}{|c|c|}
\hline Enriches recovering vegetation & Hansen et al. 1991; Lindenmayer \& McCarthy 2002 \\
\hline $\begin{array}{l}\text { Facilitates survival and population viability of various species } \\
\text { in disturbed areas }\end{array}$ & $\begin{array}{l}\text { Hutto 1995; Franklin \& MacMahon 2000; } \\
\text { Whelan } 1995\end{array}$ \\
\hline Provides habitat for species that eventually recolonize a disturbed site & Lindenmayer et al. 1997; Nappi et al. 2003 \\
\hline Promotes plant and animal recolonization of disturbed areas & Whelan 1995 \\
\hline Provides a source of energy and nutrients for other organisms & Perry 1994; Hutto 1995 \\
\hline
\end{tabular}

${ }^{*}$ Biological legacies are organisms, organically derived structures, and organically produced patterns that survive from the predisturbance system (Franklin et al. 2000) (e.g., thickets of understory vegetation, logs, patches of undisturbed or partially disturbed forest).

patterns that survive from the predisturbance system (Franklin et al. 2000). In forests, biological legacies include intact thickets of understory vegetation (Ough 2002), large living and dead overstory trees (Gibbons \& Lindenmayer 2002), logs (Harmon et al. 1986), and patches of undisturbed or partially disturbed forest (Delong \& Kessler 2000). Biological legacies can be critical for biodiversity and influence the rate and pathway of postdisturbance recovery (Franklin et al. 2000) in many ways (Table 1). Among the factors that make recently disturbed forests biologically diverse are a combination of surviving and pioneering species; diverse plant life forms and structures, which provide habitat for many organisms; high availability of light and moisture; and a variety of microclimates (Noss et al. 2006).

Salvage logging by definition removes some or all of the biological legacies created by natural disturbances and earlier mortality and patch dynamics, therefore potentially diminishing the effectiveness of some or all of the ecological roles listed in Table 1. Removal of biological legacies also simplifies the structure of forest stands (Hutto 1995; Franklin et al. 2000), homogenizes landscape pattern (Radeloff et al. 2000), and reduces connectivity between unburned areas (Morissette et al. 2002).

Dead and charred trees created by wildfires are key biological legacies lost or depleted through salvage operations (Murphy \& Lehnhausen 1998; Nappi et al. 2003). Others include malformed trees (Cooper-Ellis et al. 1999), large logs and coarse woody debris (Minshall 2003), and tip-up mounds (Cooper-Ellis et al. 1999). The removal of large quantities of biological legacies can be followed by prolonged periods of time before new ones are created. For example, the removal of burned standing trees may preclude the recruitment of large pieces of coarse woody debris to the forest floor and associated stream environments for multiple decades (Minshall 2003).

The depletion or loss of biological legacies through salvage has implications for biota dependent on them (Hutto 1995, 2006 [this issue]; Saab \& Dudley 1998; Haggard \& Gaines 2001; Morissette et al. 2002). For example, areas regenerating after fire can be rare habitats in many landscapes as a consequence of long-term fire suppression and/or historical logging practices, as well as sal- vage logging (Zackrisson 1977; Shinneman \& Baker 1997; Noss et al. 2006). Many species of animals (some rare or threatened) are attracted to places that are burning and many plants germinate in recently burned areas (Murphy \& Lehnhausen 1998; Imbeau et al. 2001; Smucker et al. 2005). Salvage logging removes key structural and other attributes from these habitats and may negatively influence species closely associated with them, thus substantially altering assemblages and communities (Morissette et al. 2002). These include taxa associated with charred standing trees and logs created by fires such as woodpeckers (Hutto 1995, 2006; Murphy \& Lehnhausen 1998; Nappi et al. 2003), carnivorous mammals (Bull et al. 2001), highly specialized beetles (Buprestidae and Ceramycidae) (Buddle et al. 2000; Grove et al. 2002), and bryophytes (Scott 1985).

The impacts of salvage logging on biodiversity have been examined in several studies. The results are variable as would be expected from work conducted across a range of forest types subject to different intensities and frequencies of human and natural disturbance (e.g., Stuart et al. 1993; Greenberg et al. 1995) and across different taxa among and within forest types (e.g., Greenberg \& McGrane 1996).

There appears to be a bias toward work on structural features of altered stands and biota associated with dead and charred trees (particularly birds and mammals), with many of these studies demonstrating or forecasting negative impacts of salvage logging (e.g., Morissette et al. 2002), although neutral or positive outcomes were reported in some investigations (Greenberg et al. 1995; Greenberg 2002) such as those of microbial assemblages (Khetmalas et al. 2002) and plants (Ne'eman et al. 1997; Elliott et al. 2002). Radeloff et al. (2000) suggest that areasensitive species in the Pine Barrens of northwestern Wisconsin (U.S.A.), such as the Sharp-tailed Grouse (Tympanuchus phasianellus), benefit from the extensive open habitats created by salvage logging.

Several studies acknowledge problems of inference related to experimental design (see McIver \& Starr 2000) such as a lack of disturbed but unsalvaged sites (Greenberg et al. 1995; Greenberg \& McGrane 1996; Elliott et al. 2002; Khetmalas et al. 2002) and/or the absence of 
predisturbance data (Greenberg et al. 1994). In addition, it is also unclear how prolonged the impacts of salvage logging may be. Work by Greenberg and Thomas (1995) shows no between-treatment differences in beetle assemblages 5-7 years after fire. In contrast, salvage logging after the 1939 Victorian wildfires has contributed to a pronounced shortage of cavity trees for more than 40 species of vertebrates-a major biodiversity conservation problem that will take more than 200 years to rectify (Lindenmayer et al. 1997).

Salvage harvesting may have impacts on biodiversity in ways other than through structural alteration of stands. For example, postdisturbance plant recovery can be changed (e.g., levels of resprouting; Cooper-Ellis et al. 1999; Lindenmayer \& Ough 2006), leading to altered composition of plant species and abundance of plant life forms (Stuart et al. 1993). For example, seedlings that germinate following a wildfire may be damaged or killed by mechanical disturbance associated with subsequent salvage logging (van Nieuwstadt et al. 2001). Natural regeneration of conifers after high-severity fire in southwestern Oregon was generally abundant in unsalvaged stands, in contrast to salvaged areas where regeneration was significantly reduced and short-term fire risk increased (Donato et al. 2006). In addition, human intervention to speed the recovery of fire-damaged and salvaged vegetation through deliberate plantings to restore tree cover may actually impair natural regeneration processes, reduce or eliminate the distinctive biodiversity of slowly recovering forests, and even create weed problems when exotic grasses and other herbaceous species are established. This is considered to be the case in the Douglas-fir (Pseudostuga menziesii [Mirb] Franco) forests of the Pacific northwest (U.S.A.), where large, naturally regenerating areas that have not been subject to salvage and replanting are extremely rare and valuable for many species (Noss et al. 2006; J. Franklin, personal communication).

\section{Salvage Logging and Ecosystem Processes}

Major disturbances can enhance ecological processes and aid ecosystem restoration by creating some of the structural complexity and landscape heterogeneity lost through past human management. For example, floods can reshape riparian areas through sediment erosion and deposition and debris movement (Bayley 1995) such that they revitalize human-modified aquatic ecosystems (Gregory 1997). Similarly, wildfires create dead wood (Angelstam 1996) and promote the development of cavities in trees (Inions et al. 1989)-structural attributes that are depleted by some forestry practices (Lindenmayer \& Franklin 2002).

Conversely, salvage logging often impairs key ecosystem processes such as hydrological regimes (e.g., soil erosion and consequent in-stream sedimentation; Helvey 1980; Karr et al. 2004; Reeves et al. 2006 [this issue]), cavity-tree formation, soil profile development, and nutrient cycling. In contrast to the natural recovery of a disturbed ecosystem, salvage harvesting has the potential to "convert a relatively intact system to a strongly modified site in which ecosystem control is reduced" (Cooper-Ellis et al. 1999:2693).

An example of the potential for salvage logging to impair ecosystem processes is the prolonged change in regional hydrological regimes that occurred after the massive "clean-up" operations that followed the 1938 hurricane in the northeastern United States (Foster et al. 1997). In a study in Portugal postfire salvage and subsequent site preparation for replanting led to sediment losses 100 times those of background levels (Shakesby et al. 1993). The horizon depth and organic content of soils under salvaged wind-blown forests in Maine were significantly more affected by subsequent fires than where salvage did not occur (Hansen 1983; M. Hunter, personal communication). Results of studies in Quebec show that salvage logging on sites subject to high-severity fires led to depleted soil calcium, magnesium, and phosphorus that will not return to prefire levels within the planned rotation time of 110 years (Brais et al. 2000). Additional road building associated with salvage logging and ground skidding of logs (which alters the properties of upper soil layers) increases both soil compaction and erosion in already fire-damaged watersheds (McIver \& Starr 2000, 2001). The sediment-catching role played by logs is lost when they are removed, which in turn may lead to significant negative impacts on aquatic ecosystems and associated macroinvertebrates (Minshall 2003). Such effects are apparent in burned catchments in southeastern Australia, where extensive salvage logging of exotic radiata pine (Pinus radiata D. Don) plantations has taken place.

\section{Salvage Harvesting and Cumulative Effects}

Organisms are typically best adapted to the disturbance regimes under which they evolved (Bergeron et al. 1999; Spies \& Turner 1999), as highlighted by examples of taxa closely associated with recently burned areas. Nevertheless, these and other species may be susceptible to novel forms and combinations of disturbances (Paine et al. 1998). For example, they may be maladapted to the interactive effects of two disturbance events in rapid succession (Paine et al. 1998), such as the compounding, cumulative, or magnified effects of following an intense natural disturbance event soon after with intensive (and often prolonged) salvage logging (van Nieuwstadt et al. 2001; Lindenmayer \& Ough 2006).

Minshall (2003) found that fire had minor and shortterm impacts on stream benthic invertebrates in the western United States. Nevertheless, in burned catchments that were subsequently salvaged, impacts were predicted to be significantly greater and more prolonged. 
Another form of cumulative effect relates to postdisturbance recovery patterns. In southeastern Asia, salvage logging of burned rainforests led to significant forest deterioration, with major negative impacts on the regenerative potential of stands and a wide range of other undesirable effects such as facilitating the colonization of invasive grassland plants (van Nieuwstadt et al. 2001). Similar effects have been reported for forests in northwestern North America (Roy 1956, in McIver \& Starr 2000). In addition, seed banks for many species may be activated following a wildfire but then exhausted if extensive mechanical harvesting follows soon after (van Nieuwstadt et al. 2001) and/or if a second fire occurs (Whelan 1995), as is the case when regeneration burns are used to promote germination of commercial-crop trees after salvage logging of fire-damaged stands in the wet forests of Victoria, southeastern Australia (Lindenmayer \& Ough 2006).

Finally, in these same forests, anecdotal information suggests that salvage logging may have impacts on key elements of stand structure that are additive to those of traditional logging. For example, large trees killed in a wildfire can remain standing for over 50 years in an unsalvaged stand (Lindenmayer et al. 1997). Conversely, firekilled trees are more likely to collapse when the surrounding stand is logged and the remaining slash is burned in a high-intensity fire applied to promote regeneration (Ball et al. 1999). In this case, two fires (a wildfire and a postharvest regeneration burn), in combination with harvesting impacts, create greater susceptibility to collapse than a single wildfire (Lindenmayer et al. 1990). Accelerated rates of tree loss create nesting-site shortages for an array of cavity-dependent vertebrates in wet eucalypt forests (Lindenmayer et al. 1997). Similar problems are likely to occur in forests in western North America where up to 150 species of vertebrates rely on dead trees for nesting and denning (Rose et al. 2001).

\section{Discussion}

Some of the impacts we have outlined may be different from or additional to the effects of traditional forms of $\log$ ging that are not preceded by large, natural disturbance events. This is because the conditions preceding, during, and after salvage logging may differ from those in areas subject to traditional logging. Moreover, the ecological benefits derived from large-scale disturbances (such as the creation of charred trees and coarse woody debris) can be lost or severely diminished by salvage operations for decades and even centuries (Lindenmayer \& Ough 2006). These problems have often been overlooked or poorly understood by conservation biologists, foresters, and other natural resource managers. In some cases salvage impacts may have been so substantial that past interpretations of ecosystem responses to natural disturbance may need to be reexamined. That is, ecosystem processes and biotic responses may have been more influenced by salvage logging than by the initial natural disturbance event. This may be true for hydrological regimes in the northeastern United States following the 1938 hurricane (Foster et al. 1997), aquatic macroinvertebrates in the western United States (Minshall 2003), and arboreal marsupials in the forests of Victoria, Australia, after the 1939 and 1983 wildfires (Lindenmayer et al. 1997).

Whereas most documented effects of salvage logging are negative from an ecological standpoint, others can be neutral or positive, depending on the response variables measured. Effects are likely to vary over time and among and within vegetation types in response to the type, intensity, and periodicity of natural disturbance and disturbance by salvage logging. Therefore, there can be no generic recipes for salvage logging that can be uncritically applied in all landscapes.

Perhaps one of the problems associated with the lack of appreciation of the impacts of salvage logging lies in the terminology itself. Dictionary definitions of the term salvage associate it with "recover or save" or "saving of anything from loss or danger" (e.g., Delbridge \& Bernard 1989). Although salvage logging removes wood from burned areas, such practices generally do not help regenerate or save ecosystems, communities, or species (but see Radeloff et al. 2000) and often have the opposite effect. Hence, in many respects, the term salvage is inappropriate and misleading from ecological and conservation perspectives. An alternative term might be postdisturbance logging.

\section{Some Ways Forward}

There needs to be broader recognition by conservation biologists and resource managers of the (1) ability of ecosystems to recover from natural disturbances (Noss et al. 2006); (2) essential role of natural disturbances in the maintenance of biodiversity and ecosystem processes (Hutto 1995; Cooper-Ellis et al. 1999; Schmiegelow et al. 2006 [this issue]); and (3) value of recently disturbed areas as rare but often critical habitats for particular elements of the biota (Murphy \& Lehnhausen 1998; Morissette et al. 2002; Noss et al. 2006). Alongside this is a need for greater recognition that the effects of human disturbances, such as logging in an environment that has been naturally disturbed, can be quite different from those of natural disturbances in isolation (Lindenmayer \& McCarthy 2002). This is clear from a commentary provided by Rackham (2001: 202) in reference to forests affected by a major windstorm in southeastern England in October 1987:

... there was an immediate sense of urgency, stoked up by the press. Action was a substitute for thought. All through that [following] very wet winter, machines galumphed through the woods, getting out timber which was sold at bottom prices ... Ecological damage done by clearing up and replanting exceeded that done by the storm itself. 
Components of an ecologically defensible salvage policy include the following measures.

(1) Exclude salvage logging entirely from some areas (Hutto 1995, 2006), such as nature reserves and water catchments (e.g., Land Conservation Council 1994), extensive areas of old-growth forest, and places with few or no roads (Trombulak \& Frissell 2000). Sensitive sites such as steep slopes and fragile or highly erodable soils also should be exempt from salvage harvesting (Minshall 2003; Karr et al. 2004).

(2) Ensure that unburned or partially burned patches within the perimeter of a disturbed area (e.g., see De Long \& Kessler 2000) are either exempt from salvage or subject to low-intensity harvesting with high levels of legacy retention.

(3) Ensure that certain biological legacies are retained in salvage-logged areas such as fire-damaged trees (Hutto 1995; Nappi et al. 2004) and large (damaged or undamaged) commercially valuable trees (Morissette et al. 2002). These often have either high habitat value (e.g., for foraging by woodpeckers; Nappi et al. 2003) or a high probability of remaining standing for a prolonged period (Gibbons \& Lindenmayer 2002).

(4) Modify salvage policies to limit the amounts of biological legacies that are removed from particular sorts of areas (Hobson \& Schieck 1999)-such as from burned old-growth stands within wood-production zones as currently occurs in some parts of northwestern North America (e.g., Forest Ecosystem Management Team 1993).

(5) Schedule salvage logging so that effects on natural recovery of vegetation are limited (e.g., Roy 1956 in McIver \& Starr 2000; van Niuewstadt et al. 2001). This suggestion is related to a need to appraise the ability of disturbed stands to recover naturally (Cooper-Ellis et al. 1999) and, hence, the ecological desirability of programs to replant fire-damaged areas (Noss et al. 2006).

(6) Related to the points above, ensure the future maintenance or creation of particular habitat elements for species of conservation concern within burned areas potentially subject to salvage logging, such as some woodpeckers (Hutto 1995; Smucker et al. 2005), rare forest carnivores (Bull et al. 2001), cavity-using mammals (Lindenmayer \& Ough 2006), invertebrates (Hoyt \& Hannon 2002), and plants (Scott 1985).

(7) Ensure adequate riparian buffers are in place to protect aquatic ecosystems within areas where salvageharvesting operations occur (Minshall 2003), and retain structures such as logs and logging slash on the ground to limit soil erosion (Shakesby et al. 1993).

(8) The effects of ground-based logging on soil and water in postdisturbance environments can be great; thus, this type of harvesting should be limited and, when- ever possible, replaced with cable or helicopter systems for removing fire-burned trees.

A key part of better management of salvage logging is the acquisition of new knowledge to inform policies and on-the-ground operations. Although extensive research has been undertaken on the impacts of many types of disturbances (fire, logging, windstorms), remarkably little work has been conducted on salvage operations that often follow them (McIver \& Starr 2000; Morissette et al. 2002). This knowledge gap needs to be addressed urgently, particularly given (1) current plans for extensive salvage operations following major natural disturbances in North America, Australia, Asia, and Europe (Lindenmayer et al. 2004; Schmiegelow et al. 2006); (2) that wood salvaged from disturbed areas is an increasing proportion of harvest volume in some regions (e.g., western North America; McIver \& Starr 2000); and (3) that climate change may increase the frequency of major disturbance events such as wildfires (e.g., see Lenihan et al. 2003 for predictions for California) and insect attacks (e.g., in Canada, Shore et al. 2003) and this in turn will result in increased demands for salvage logging (Spittlehouse \& Stewart 2003).

Prescriptions for the retention of biological legacies in salvaged areas are poorly formulated in many jurisdictions (e.g., Quebec; Nappi et al. 2003, 2004). Until research can catch up with the needs of forest managers, guidelines for legacy retention should be based on knowledge and understanding generated by studies of natural disturbance regimes (Lindenmayer \& McCarthy 2002; Noss et al. 2006), such as the quantities, types, and spatial arrangements of biological legacies (Franklin et al. 2000). Moreover, in cases where salvage logging is permitted, well-designed experiments, natural experiments, observational studies, and monitoring programs should be established so that impacts can be investigated and rigorously compared with both undisturbed parts of landscapes and disturbed areas exempt from harvesting.

\section{Acknowledgments}

We gratefully acknowledge the contribution to and the support of this special section by G. Tabor of the Wilburforce Foundation. We also thank a range of colleagues who provided many useful ideas and comments on salvage logging issues including $\mathrm{R}$. Cunningham, M. McCarthy, M. Hunter, J. Franklin, D. Foster, F. Schmiegelow, and A. Manning. Critical comments from a range of colleagues, particularly R. Beschta and D. DellaSala, improved earlier versions of this paper. S. Singh assisted with editing of this paper and the entire special section.

\section{Literature Cited}

Amman, G. D., and K. C. Ryan. 1991. Insect infestation of fire-injured trees in the greater Yellowstone area. Research note INT-398. U.S. 
Department of Agriculture Forest Service, Intermountain Research Station, Ogden, Utah.

Angelstam, P. 1996. The ghost of forest past-natural disturbance regimes as a basis for reconstruction for biologically diverse forests in Europe. Pages 287-337 in R. M. DeGraaf and R. I. Miller, editors. Conservation of faunal diversity in forested landscapes. Chapman and Hall, London.

Ball, I., D. B. Lindenmayer, and H. P. Possingham. 1999. HOLSIM: a model for simulating hollow availability in managed forest stands. Forest Ecology and Management 123:179-194.

Bayley, P. B. 1995. Understanding large river-floodplain ecosystems. BioScience 45:153-158.

Bergeron, Y., B. Harvey, A. Leduc, and S. Gauthier. 1999. Forest management guidelines based on natural disturbance dynamics: stand- and forest-level considerations. Forestry Chronicle 75:49-54.

Beschta, R., J. J. Rhodes, J.B. Kauffman, R. E. Gresswell, G. W. Minshall, J. R. Karr, D. A. Perry, F. R. Hauer, and C. A. Frissell. 2004. Postfire management on forested public lands of the Western United States. Conservation Biology 18:957-967.

Bradstock, R. A., J. E. Williams, and A. M. Gill, editors. 2002. Flammable Australia. The fire regimes and biodiversity of a continent. Cambridge University Press, Melbourne.

Brais, S., P. David, and R. Ouimet. 2000. Impacts of wild fire severity and salvage harvesting on the nutrient balance of Jack Pine and Black Spruce boreal stands. Forest Ecology and Management 137:231243

Brooks, R. T. 2001. Effects of removal of overstorey hemlock from hemlock-dominated forests on Eastern Redback Salamanders. Forest Ecology and Management 149:197-204.

Bryant, E. A. 2001. Tsunami: the underrated hazard. Cambridge University Press, Cambridge, United Kingdom.

Buddle, C. M., J. R. Spence, and D. W. Langor. 2000. Succession of forest spider assemblages following wildfire and harvesting. Ecography 23:424-436.

Bull, E. L., K. B. Aubry, and B. C. Wales. 2001. Effects of disturbance on forest carnivores of conservation concern in eastern Oregon and Washington. Northwest Science 75(Special Issue S1):180-184.

Bunnell, F. 1995. Forest-dwelling fauna and natural fire regimes in British Columbia: patterns and implications for conservation. Conservation Biology 9:636-644.

Burton, P. J., C. Messier, D. W. Smith, and W. L. Adamowicz. 2003. Towards sustainable management of the boreal forest. National Research Council of Canada, Ottawa.

Cooper-Ellis, S., D. R. Foster, G. Carlton, and A. Lezberg. 1999. Forest response to catastrophic wind: results from an experimental hurricane. Ecology 80:2683-2696

Delbridge, A., and J. Bernard, editors. 1989. Macquarie dictionary. 2nd edition. The Jacaranda Press, Milton, Queensland, Australia.

Delong, S. C., and W. B. Kessler. 2000. Ecological characteristics of mature forest remnants left by wildfire. Forest Ecology and Management 131:93-106.

Donato, D. C., J. B. Fontaine, J. L. Campbell, W. D. Robinson, J. B. Kauffman, and B. E. Law. 2006. Post-wildfire logging hinders regeneration and increases fire risk. Science 311:352.

Elliott, K. J., S. L. Hitchcock, and L. Krueger. 2002. Vegetation response to large scale disturbance in a southern Appalachian forest: hurricane Opal and salvage logging. Journal of the Torrey Botanical Society 129: $48-59$.

Foster, D. R., J. B. Aber, J. M. Melillo, R. D. Bowden, and F. A. Bazzaz. 1997. Forest response to disturbance and anthropogenic stress. BioScience 47:437-445.

Franklin, J. F., and J. K. Agee. 2003. Forging a science-based national forest fire policy. Issues in Science and Technology 20:59-66.

Franklin, J. F., and J. A. MacMahon. 2000. Messages from a mountain. Science 288:1183-1185.

Franklin, J. F., D. B. Lindenmayer, J. A. MacMahon, A. McKee, J. Magnusson, D. A. Perry, R. Waide, and D. R. Foster. 2000. Threads of continuity: ecosystem disturbances, biological legacies and ecosystem recovery. Conservation Biology in Practice 1:8-16.

Gibbons, P., and D. B. Lindenmayer. 2002. Tree hollows and wildlife conservation in Australia. CSIRO Publishing, Melbourne.

Greenberg, C. H. 2002. Response of white-footed mice (Peromyscus leucopus) to coarse woody debris and microsite use in southern Appalachian tree falls. Forest Ecology and Management, 164:57-66.

Greenberg, C. H., and A. McGrane. 1996. A comparison of relative abundance and biomass of ground-dwelling arthropods under different forest management practices. Forest Ecology and Management 89:31-41.

Greenberg, C. H., and M. C. Thomas. 1995. Effects of forest management practices on terrestrial coleopteran assemblages in Sand Pine Scrub. Florida Entomologist 78:271-285.

Greenberg, C. H., D. G. Neary, and L. D. Harris. 1994. Effects of highintensity wildfire and silvicultural treatments on reptile communities in Sand Pine Scrub. Conservation Biology 8:1047-1057.

Greenberg, C. H., L. D. Harris, and D. G. Neary. 1995a. A comparison of bird communities in burned and salvaged-logged clearcut, and forested Florida Sand Pine Scrub. Wilson Bulletin 107:40-54.

Greenberg, C. H., D. G. Neary, L. D. Harris, and S. P. Linda. $1995 b$. Vegetation recovery following high-intensity wildfire and silvicultural treatments in Sand Pine Scrub. American Midland Naturalist 133:149-163.

Gregory, S. V. 1997. Riparian management in the 21st century. Pages 69-85 in K. A. Kohm, and J. F. Franklin editors. Creating a forestry for the 21st century. Island Press, Washington, D.C.

Grove, S. J., J. F. Meggs, and A. Goodwin. 2002. A review of biodiversity conservation issues relating to coarse woody debris management in the wet eucalypt production forests of Tasmania. Forestry Tasmania, Hobart, Australia.

Haggard, M., and W. L. Gaines. 2001. Effects of stand replacement fire and salvage logging on a cavity-nesting bird community in eastern Cascades, Washington. Northwest Science 75:387-396.

Hansen, A., and J. Rotella. 1999. Abiotic factors. Pages 161-209 in M. Hunter III, editor. Managing biodiversity in forest ecosystems. Cambridge University Press, Cambridge, United Kingdom.

Hansen, A. J., T. A. Spies, F. J. Swanson, and J. L. Ohmann. 1991 Conserving biodiversity in managed forests. Bioscience 41:382392.

Harmon, M., et al. 1986. Ecology of coarse woody debris in temperate ecosystems. Advances in Ecological Research 15:133-302.

Helvey, J. D. 1980. Effects of a north central Washington wildfire on runoff and sediment production. Water Resources Bulletin 16:627634.

Hobson, K. A., and J. Schieck. 1999. Changes in bird communities in boreal mixedwood forest: harvest and wildfire effects over 30 years. Ecological Applications 9:849-863.

Holling, C. S., D. W. Schindler, B. W. Walker, and J. Roughgarden. 1995. Biodiversity in the functioning of ecosystems: an ecological primer and synthesis. Pages 44-83 in D. Pimentel et al., editors. Biodiversity loss: economic and Ecological Issues. Cambridge University Press, Cambridge, United Kingdom.

Hoyt, J. S., and S. J. Hannon. 2002. Habitat associations of black-backed and three-toed woodpeckers in the boreal forest of Alberta. Canadian Journal of Forest Research 32:1881-1888.

Hunter, M. L., editor. 1999. Managing biodiversity in forest ecosystems. Cambridge University Press, London.

Hutto, R. 1995. Composition of bird communities following standreplacement fires in northern Rocky Mountain conifer forests. Conservation Biology 9:1041-1058.

Hutto, R. L. 2006. Are current snag management guidelines appropriate for post-fire salvage logging in severely burned forests? Conservation Biology 20:DOI: 10.1111/j.1523-1739.2006.00494.x.

Imbeau, L., M. Mönkkönen, and A. Descrochers. 2001. Long-term effects of forestry on birds of the eastern Canadian boreal forests: a comparison with Fennoscandia. Conservation Biology 15:1151-1162. 
Inions, G., M. T. Tanton, and S. M. Davey. 1989. Effects of fire on the availability of hollows in trees used by the Common Brushtail Possum, Trichosurus vulpecula Kerr 1792, and the Ringtail Possum, Pseudocheirus peregrinus Boddaerts 1785. Australian Widlife Research 16:449-458.

Karr, J. R., J. J. Rhodes, G. W. Minshall, F. R. Hauer, R. L. Beschta, C. A. Frissell, and D. A. Perry. 2004. The effects of postfire salvage logging on aquatic ecosystems in the American west. BioScience 54:10291033.

Khetmalas, M. B., K. N. Egger, H. B. Massicotte, L. E. Tackaberry, and M. J. Clapperton. 2002. Bacterial diversity associated with Subalpine Fir (Abies lasiocarpa) ectomycorrhizae following wildfire and salvagelogging in central British Columbia. Canadian Journal of Microbiology 48:611-625.

Land Conservation Council. 1994. Final recommendations. Melbourne Area. District 2 Review. Land Conservation Council, Melbourne, Australia.

Lenihan, J. M., R. Drapek, D. Bachelet, and R. P. Neilson. 2003. Climate change effect on vegetation distribution, carbon, and fire in California. Ecological Applications 13:1667-1681.

Lindenmayer, D. B., and J. F. Franklin. 2002. Conserving forest biodiversity: a comprehensive multiscaled approach. Island Press, Washington, D.C.

Lindenmayer, D. B., and M. A. McCarthy. 2002. Congruence between natural and human forest disturbance-an Australian perspective. Forest Ecology and Management 155:319-335.

Lindenmayer, D. B., and K. Ough. 2006. Salvage logging in the montane ash eucalypt forests of the Central Highlands of Victoria and its potential impacts on biodiversity. Conservation Biology 20:DOI: 10.1111/j.1523-1739.2006.00501.x.

Lindenmayer, D. B., R. B. Cunningham, M. T. Tanton, and A. P. Smith. 1990. The conservation of arboreal marsupials in the montane ash forests of the Central Highlands of Victoria, south-east Australia. II. The loss of trees with hollows and its implications for the conservation of Leadbeaters possum Gymnobelideus leadbeateri McCoy (Marsupialia: Petauridae). Biological Conservation 54:133145.

Lindenmayer, D. B., R. B. Cunningham, and C. F. Donnelly. 1997. Tree decline and collapse in Australian forests: implications for arboreal marsupials. Ecological Applications 7:625-641.

Lindenmayer, D. B., D. Foster, J. F. Franklin, M. Hunter, R. Noss, F. Schiemegelow, and D. Perry. 2004. Salvage harvesting after natural disturbance. Science 303:1303.

McIver, J. D., and L. Starr, technical editors. 2000. Environmental effects of postfire logging: literature review and annotated bibliography. PNW-GTR-486. Pacific Northwest Research Station, Portland, Oregon.

McIver, J. D., and L. Starr. 2001. A literature review on the environmental effects of postfire logging. Western Journal of Applied Forestry 16:159-168.

Minshall, G. W. 2003. Responses of stream benthic macroinvertebrates to fire. Forest Ecology and Management 178:155-161.

Morissette, J. L., T. P. Cobb, R. M. Brigham, and P. C. James. 2002. The response of boreal forest songbird communities to fire and post-fire harvesting. Canadian Journal of Forest Research 12:2169-2183.

Murphy, E. C., and W. A. Lehnhausen. 1998. Density and foraging ecology of woodpeckers following a stand replacement fire. Journal of Wildlife Management 62:1359-1372.

Nappi, A., P. Drapeau, J. F. Giriouux, and J. F. Savard. 2003. Snag use by foraging Black-backed woodpeckers (Picoides artious) in a fecently burned eastern boreal forest. Auk 120:505-511.

Nappi, A., P. Drapeau, and J. F. Savard. 2004. Salvage logging after wildfire in the boreal forest: is it becoming a hot issue for wildlife? The Forestry Chronicle 80:67-74.

Ne'eman, G., A. Perevolotsky, and G. Schiller. 1997. The management implications of the Mt. Carmel research project. International Journal of Wildland Fire 7:343-350.
Noss, R. F., J. F. Franklin, W. L. Baker, T. Schoennagel, and P. B. Moyle. 2006. Ecology and management of fire-prone forests of the western United States. Society for Conservation Biology Scientific Panel or Fire in Western U.S. Forests. Society for Conservation Biology, North American section, Arlington, Virginia. Also available from www.conbio.org/sections/namerica/napolicy.cfm.

Ough, K. 2002. Regeneration of wet forest flora a decade after clearfelling or wildfire-is there a difference? Australian Journal of Botany 49:645-664.

Pahl-Wostl, C. 1995. The dynamic nature of ecosystems: chaos and order entwined. Wiley, New York.

Paine, R. T., M. J. Tegner, and E. A. Johnson. 1998. Compounded perturbations yield ecological surprises. Ecosystems 1:535-545.

Perry, D. A. 1994. Forest ecosystems. Johns Hopkins Press, Baltimore, Maryland.

Pickett, S. T. A., V. T. Parker, and P. Fielder. 1992. The new paradigm in ecology: implications for conservation biology above the species level. Pages 65-88 in P. Fielder, and S. Jain, editors. Conservation Biology: the theory and practice of nature conservation. Chapman and Hall, New York.

Rackham, O. 2001. Trees and woodland in the British landscape. Revised edition. Phoenix Press, London.

Radeloff, V. C., D. J. Mladenoff, and M. S. Boyce. 2000. Effects of interacting disturbances on landscape patterns: budworm defoliation and salvage logging. Ecological Applications 10:233-247.

Reeves, G. H., P. A. Bisson, B. E. Rieman, and L. E. Benda. 2006. Postfire logging in riparian areas. Conservation Biology 20:DOI: 10.1111/j.1523-1739.2006.00502.x.

Rose, C., B. G. Marcot, T. K. Mellen, J. L. Ohmann, K. Waddell, D. Lindley, and B. Schreiber. 2001. Decaying wood in Pacific Northwest forests: concepts and tools for habitat management. Pages 580623 in D. Johnson, and T. O'Neil, editors. Wildlife-habitat relationships in Oregon and Washington. Oregon State University Press, Corvallis.

Rübsamen, K., I. D. Hume, W. J. Foley, and U. Rübsamen. 1984. Implications of the large surface area to body mass ratio on the heat balance of the greater glider (Petauroides volans: Marsupialia). Journal of Comparative Physiology 154:105-111.

Robinson, G., and J. Zappieri. 1999. Conservation policy in time and space: lessons from divergent approaches to salvage logging on public lands. Conservation Ecology 3:http://www.consecol.org/vol3/ iss1/art3.

Rülcker, C., P. Angelstam, and P. Rosenberg. 1994. Natural forest-fire dynamics can guide conservation and silviculture in boreal forests. SkogForsk 2:1-4.

Saab, V. J., and J. Dudley. 1998. Responses of cavity-nesting birds to standreplacement fire and salvage logging in Ponderosa Pine/DouglasFir forests of southwestern Idaho. Research paper RMRS-RP-11. U.S. Department of Agriculture Forest Service, Rocky Mountain Research Station, Ogden, Utah.

Schmiegelow, F. K. A., D. P. Stepnisky, C. A. Stambaugh, and M. Koivula. 2006. Reconciling salvage logging of boreal forests with a naturaldisturbance management model. Conservation Biology 20:DOI: 10.1111/j.1523-1739.2006.00496.x.

Schoener, T. W., D. A. Spiller, and J. B. Losos. 2004. Variable ecological effects of hurricanes: the importance of seasonal timing for survival of lizards on Bahamian islands. Proceedings of the National Academy of Sciences of the United States of America 101:177-181.

Scott, G. A. 1985. Southern Australian liverworts. Bureau of Flora and Fauna, Australian Government Publishing Service, Canberra, Australia.

Sessions, J., P. Bettinger, R. Buckman, M. Newton, and J. Hamann. 2004. Hastening the return of complex forests following fire: the consequences of delay. Journal of Forestry 102:38-45.

Shakesby, R. A., C. Coelho, and A. D. Ferreira. 1993. Wildfire impacts on soil erosion and hydrology in wet mediterranean forest, Portugal. International Journal of Wildland Fire 3:95-110. 
Shakesby, R. A., D. J. Boakes, and C. Coelho. 1996. Limiting the soil degradational impacts of wildfire in pine and Eucalyptus forests in Portugal: a comparison of alternative post-fire management practices. Applied Geography 16:337-355.

Shiel, D., and F. R. Burslem. 2003. Disturbing hypotheses in tropical forests. Trends in Ecology \& Evolution 18:18-26.

Shinneman, D. J., and W. L. Baker. 1997. Nonequilibrium dynamics between catastrophic disturbances and old growth forests in Ponderosa Pine landscapes of the Black Hills. Conservation Biology 11:1276-1288.

Shore, T. L., J. E. Brooks, and J. E. Stone, editors. 2003. Mountain pine beetle symposium: challenges and solutions. Information report BCX-399. Natural Resources Canada, Canadian Forest Service and Pacific Forestry Centre, Victoria, British Columbia.

Smucker, K. M., R. L. Hutto, and B. M. Steele. 2005. Changes in bird abundance after wildfire: importance of fire severity and time since fire. Ecological Applications 15:1535-1549.

Spies, T. A., and M. G. Turner. 1999. Dynamic forest mosaics. Pages 95-160 in M. Hunter Jr., editor. Managing biodiversity in forest ecosystems. Cambridge University Press, Cambridge, United Kingdom.

Spittlehouse, D. L., and R. B. Stewart. 2003. Adaptation to climate change in forest management. BC Journal of Ecosystems and Management 4:1-11.

Stuart, J. D., M. C. Grifantini, and L. Fox. 1993. Early successional pathways following wildfire and subsequent silvicultural treatment in Douglas-Fir hardwood forests, NW California. Forest Science 39:561-572.

Trombulak, S. C., and C. A. Frissell. 2000. Review of ecological effects of roads on terrestrial and aquatic communities. Conservation Biology 14:18-30.

Turner, M. G., W. H. Romme, and D. B. Tinker. 2003. Surprises and lessons from the 1988 Yellowstone fires. Frontiers in Ecology and Environment 1:351-358.

Ulbricht, R., A. Hinrichs, and Y. Ruslim. 1999. Technical guideline for salvage felling in rehabilitation areas after forest fires. Report 1 . The Sustainable Forest Management Project, Samarinda, Indonesia.

Van Nieuwstadt, M. G., D. Shiel, and K. Kartawinata. 2001. The ecological consequences of logging in the burned forests of east Kalimantan, Indonesia. Conservation Biology 15:1183-1186.

Whelan, R. J. 1995. The ecology of fire. Cambridge studies in ecology. Cambridge University Press, Cambridge, United Kingdom.

Zackrisson, O. 1977. Influence of forest fires on the north Swedish boreal forest. Oikos 29:22-32.

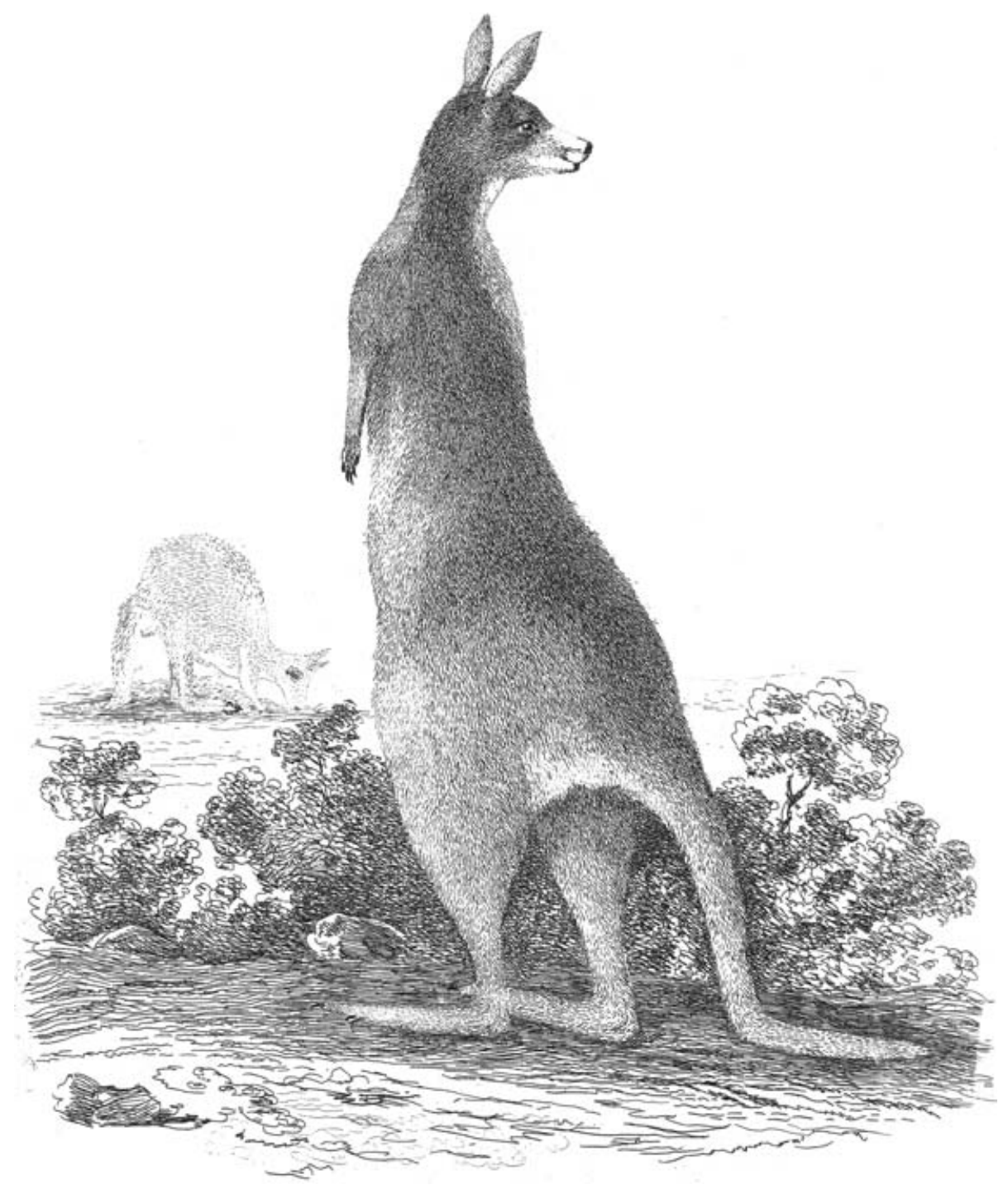

